Terakreditasi Sinta 3 | Volume 3 | Nomor 4 (Special Issue) | Tahun 2020 | Halaman 365-372

P-ISSN 2615-725X | E-ISSN 2615-8655

http://diglosiaunmul.com/index.php/diglosia/article/view/100

\title{
STUDI EKSPLORATIF KEBUTUHAN PEMBELAJARAN DARING UNTUK MATA KULIAH MENYIMAK PADA MASA PANDEMI COVID-19
}

\author{
Explorative Study of the Needs Online Learning for Listening Learning \\ in the Covid-19 Pandemic
}

\author{
Elvrin Septyanti ${ }^{1}$ \& Otang Kurniaman ${ }^{2, *}$ \\ ${ }^{1,2}$ Fakultas Keguruan dan Ilmu Pendidikan, Universitas Riau \\ ${ }^{1}$ Pos-el: elvrin.septyanti@lecturer.unri.ac.id \\ 2,* Pos-el korespondensi: otang.kurniaman@lecturer.unri.ac.id
}

\begin{abstract}
The purpose of this research is to describe the needs of students of the Indonesian Language and Satra Education study program related to the aspects of reading materials and platforms that can facilitate the online learning process during the Covid-19 pandemic. The method used in this study is a qualitative exploratory method with an inductive approach. Through this method, data is obtained based on questionnaire documentation distributed via google form. The research sample was obtained through purposive sampling technique from three universities in Riau: Riau University, Suska Riau Islamic State University, and Riau Islamic University. Furthermore, this study uses thematic data analysis techniques to identify themes through the results of the questionnaire to find important or interesting patterns from the data and use these to discuss or find the purpose of this study. The results of the analysis show that students need teaching materials in the form of audio in the form of narrative voices to hone and test their listening skills specifically for listening only. Then, students also need to listen to audio-visual in the form of videos to bone and test the overall listening power of these students. Because during the Covid-19 pandemic, all the things needed to listen to that which were of great interest to students were published online through digital classes with the Google Classroom platform. This is evidenced by the results of a survey of $64 \%$ of students requiring online learning with audio, visual, audio-visual teaching materials through Google Classroom digital classes. The results of this need are used to develop learning materials as a form of innovative learning products during the Covid-19 pandemic on campus.
\end{abstract}

Keywords: explorative study, need of online learning, listening learning

Abstrak: Tujuan penelitian ini untuk mendeskripsikan kebutuhan mahasiswa program studi Pendidikan Bahasa dan Satra Indonesia terkait aspek bahan simakan dan platform yang dapat mempermudah proses pembelajaran daring selama masa pandemi covid-19. Metode yang digunakan dalam penelitian ini yaitu metode kualitatif eksploratif dengan pendekatan induktif.. Melalui metode ini, data diperoleh berdasarkan dokumentasi angket yang didistribusikan melalui Google Form. Sampel penelitian diperoleh melalui teknik purposive sampling yang berasal dari tiga perguruan tinggi di Riau: Universitas Riau, Universitas Islam Negeri Suska Riau, dan Universitas Islam Riau. Selanjutnya, penelitian ini menggunakan teknik analisis data tematik untuk mengidentifikasi tema melalui hasil angket akan ditemukan pola yang penting atau menarik dari data dan menggunakan hal tersebut untuk membahas atau menemukan tujuan dari penelitian ini. Hasil analisis menunjukkan bahwa mahasiswa membutuhkan bahan ajar dalam bentuk audio berupa suara yang bernarasi guna mengasah dan menguji kemampuan menyimak khusus untuk mendengar saja. Kemudian, mahasiswa juga membutuhkan menyimak audio-visual berupa video guna mengasah dan menguji daya simak keseluruhan dari mahasiswa tersebut. Karena dalam masa pandemi Covid-19 keseluruhan hal yang dibutuhkan dalam menyimak tersebut yang sangat diminati mahasiswa ialah dimuat dalam bentuk daring melalui kelas digital dengan platform Google Classroom. Hal itu dibuktikan dengan hasil survei sebesar $64 \%$ mahasiswa membutuhkan pembelajaran daring dengan bahan ajar audio, visual, audio- 
visual melalui kelas digital Google Classroom. Hasil kebutuhan ini digunakan untuk mengembangkan bahan simakan sebagai bentuk inovasi produk pembelajaran di masa pandemi Covid-19 di kampus. Kata kunci: studi eksploratif, kebutuhan pembelajaran daring, mata kuliah menyimak

\section{A. PENDAHULUAN}

Awal tahun 2020 dunia dikejutkan kemunculan virus covid-19 yang penyebarannya sampai ke Indonesia. Bahkan pada tanggal 11 Maret, 2020 World Health Organization (WHO) bahkan telah mendeklarasikan kejadian ini sebagai pandemi global (Cucinotta \& Vanelli, 2020). Hal ini pun secara tidak langsung melumpuhkan aktivitas pendidikan dalam rangka pembelajaran tatap muka mulai dari pendidikan anak usia dini sampai perguruan tinggi tidak bisa melakukan pembelajaran seperti biasa. Pemerintah pun mengambil keputusan melalui Kementerian Pendidikan dan Kebudayaan melarang segala bentuk pertemuan dalam rangka pembelajaran tatap muka seperti biasa untuk diganti secara daring (Surat Edaran Ditjen Dikti Kemendikbud No. 1 Tahun 2020). Pembelajaran daring adalah pembelajaran yang mampu mempertemukan mahasiswa dan dosen untuk melaksanakan interaksi pembelajaran dengan bantuan internet (Kuntarto, 2017). Hal ini disebabkan salah satu penularan virus tersebut melalui kedekatan yang biasa kita lakukan dalam pembelajaran sehari-hari antar manusia yang satu dengan yang lainnya tanpa bisa terlihat oleh mata sehingga perlu adanya pembatasan pertemuan guna mencegah penyebaran virus tersebut secara masif. Menurut Stein (2020) melakukan social distancing sebagai solusi yang baik untuk mencegah penyebaran Covid-19. Perkuliahan harus diselenggarakan dengan skenario yang mampu mencegah berhubungan secara fisik antara mahasiswa dengan dosen maupun mahasiswa dengan mahasiswa (Firman, F., \& Rahayu, S., 2020). Hal ini dilakukan karena taruhannya nyawa bahkan satu nyawa yang hilang karena positif Covid-19 bisa mengundang ratusan ribu nyawa yang lain hilang seperti yang terjadi di Amerika dan Brazil. Pembelajaran daring dengan teknologi digital inilah sebagai salah satu cara guna memperkecil kemungkinan nyawa melayang karena virus ini di negara kita. Menurut Milman (2015) penggunaan teknologi digital dapat memungkinkan mahasiswa dan dosen melaksanakan proses pembelajaran walaupun mereka di tempat yang berbeda. Pembelajaran, pengajaran, dan pendidikan pasti terhambat, terlambat bahkan cuma jalan di tempat gara-gara skema daring ini dari pada nyawa ratusan juta tongkat generasi yang ada di sekolah, lembaga pendidikan sampai di kampus hilang begitu saja terkubur tanah.

Pembelajaran daring dibutuhkan dalam pembelajaran di era revolusi industri 4.0 (Pangondian, Santosa, \& Nugroho, 2019). Apalagi sekelas perguruan tinggi pembelajaran daring ini sudah jauh dimulai hanya saja penerapannya yang kurang dimaksimalkan. Pandemi ini merupakan konteks yang sangat tepat dalam kita berinovasi menggali kreativitas pembelajaran daring dengan menyusun skema yang sederhana, tepat dan akurat walaupun tanpa tatap muka seperti biasa.

Terlebih lagi, salah satu pembelajaran yang mendapat tantangan pada masa pandemi saat ini adalah mata kuliah menyimak. Belum lagi, selama ini, komponen pembelajaran belum maksimal dirancang secara baik. Dari aspek media, media yang digunakan biasanya berupa audio visual seperti yang diunduh melalui Youtube dan atau menggunakan bahan simakan yang tidak terintegrasi secara daring. Materi yang diambil berupa cuplikan pidato, cuplikan berita, dan atau mahasiswa secara kreatif merekam sendiri 
bahan simakan untuk diperdengarkan kepada mahasiswa lain. Evaluasi keterampilan menyimak sebagai pedoman nilai evaluasi masih hanya diukur berdasarkan uji materi saja. Padahal, pada keterampilan menyimak, uji keterampilan menyimak melalui kegiatan mendengarkan juga perlu dilakukan. Artinya, mata kuliah menyimak menjadi salah satu mata kuliah yang dituntut menyiapkan bahan ajar yang dapat diterima secara daring. Jika tidak, pembelajaran menyimak hanya akan menyampaikan materi secara teoretis saja tanpa melatih keterampilan menyimak mahasiswa.

Hal ini yang mendasari penelitian dilakukan. Penelitian ini dianggap perlu dengan cara adanya analisis kebutuhan dalam rangka inovasi pembelajaran di perguruan tinggi dalam menanggulangi pendidikan di tengah pandemi sehingga bisa berjalan dengan efektif dan efisien dengan tidak mengurangi capaian kompetensi yang diharapkan pada mahasiswa. Hal inilah yang penulis rancang untuk berinovasi dalam pembelajaran menyimak dimasa pandemi Covid-19. Penelitian ini bertujuan untuk mendeskripsikan kebutuhan mahasiswa program studi Pendidikan Bahasa dan Satra Indonesia terkait aspek bahan simakan dan platform yang dapat mempermudah proses pembelajaran daring mata kuliah menyimak selama masa pandemi Covid-19.

Karena pembelajaran tatap muka dilarang, bagaimana dosen bisa mengajarkan mata kuliah menyimak tanpa adanya pembelajaran tatap muka. Apa yang bisa disimak mahasiswa dan apa yang bisa diberikan dosen untuk mata kuliah menyimak dengan kondisi seperti ini. Tentu akan rumit, sulit dan bahkan membingungkan bagi kedua belah pihak untuk melakukan pembelajaran. Hal ini akan menjadi kesulitan tersendiri dalam pembelajaran menyimak. Penulis akan menyelesaikan permasalahan tersebut melalu inovasi pengembangan dengan mengawalinya melalui analisis kebutuhan sebagai potensi pengembangan dalam pembelajaran untuk mata kuliah menyimak. Penelitian ini sebagai cikal bakal awal pengembangan dengan mengidentifikasi apa yang dibutuhkan mahasiswa untuk mata kuliah menyimak dengan keadaan di masa pandemi Covid19 ini.

\section{B. METODE}

Penelitian ini menggunakan metode kualitatif eksploratif dengan pendekatan induktif. Hal ini bertujuan untuk menggali secara luas dan mendalam tentang sebabsebab atau hal-hal yang mempengaruhi terjadinya sesuatu. Metode ini digunakan untuk mendapatkan informasi kebutuhan pembelajaran menyimak dimasa pandemi Covid-19. Penelitian ini tidak menggunakan istilah populasi tetapi oleh Spradley (dalam Sugiyono, 2007, hlm. 49) dinamakan social situation atau situasi sosial yang terdiri dari tiga elemen yaitu: tempat, pelaku dan aktivitas. Pada situasi sosial atau obyek penelitian ini penelitian dapat mengamati secara mendalam aktivitas orang-orang yang ada pada tempat tertentu. Teknik pengumpulan data berupa angket yang disebar pada mahasiswa di tiga perguruan tinggi Universitas Riau, Universitas Islam Negeri SUSKA Riau, dan Universitas Islam Riau dengan menggunakan purposive sampling. Teknik analisis data menggunakan teknik analisis tematik. Clarke \& Braun menjelaskan tujuan analisis tematik adalah mengidentifikasi tema melalui hasil angket akan ditemukan pola yang penting atau menarik dari data dan menggunakan hal tersebut untuk membahas atau menemukan tujuan dari penelitian ini (Utarini, 2020, hlm. 287).

\section{PEMBAHASAN}

Penelitian ini mengambil sampel dari tiga universitas terdepan di Riau pada Prodi Bahasa dan Sastra Indonesia sebagai acuan yang tepat dalam memenuhi 
hipotesis bahwa pembelajaran daring hal yang tepat pada kondisi dalam pandemi Covid-19. Penelitian ini mengacu pada angket yang telah disusun sebelumnya guna memfasilitasi penulis dan objek data dalam mengidentifikasi permasalahan yang jadi kebutuhan dalam pembelajaran menyimak di masa pandemi. Penulis menyusun 20 poin untuk mengungkap kebutuhan dalam pembelajaran daring mata kuliah menyimak di masa pandemi bagi mahasiswa di tiga universitas di Riau sebagai berikut.

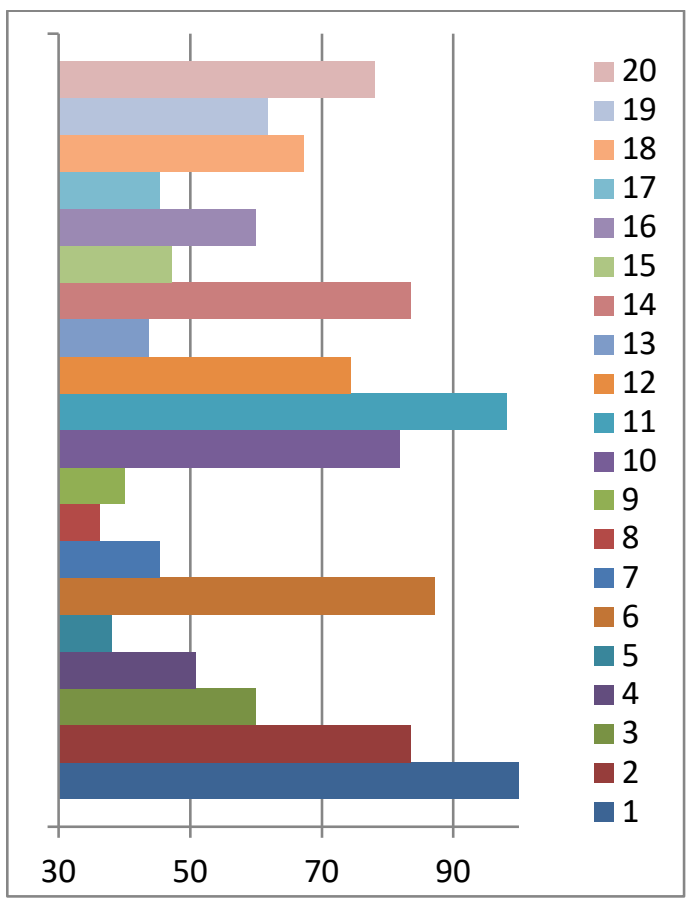

\section{Gambar 1. Rekap Studi Eksplorasi}

Berdasarkan diagram tersebut penulis menemukan permasalahan dan kebutuhan mahasiswa dalam pembelajaran menyimak dimasa pandemi Covid-19. Hal ini berkaitan dengan lika-liku perkuliahan menyimak dimasa pandemi yang sudah masuk ke "era baru" dengan melibatkan teknologi daring guna menjalankan pembelajaran di setiap jenjang. Ada dua hal besar yang penulis paparkan berdasarkan temuan di lapangan sebagai berikut.
1. Permasalahan Pembelajaran

a. Pembelajaran Menyimak Dilakukan secara Konvensional

Hasilnya $87 \%$ mahasiswa mengalami perkuliahan ini. Hal ini yang selalu dilakukan dosen dan mahasiswa dalam perkuliahan menyimak. Identifikasi ini menunjukkan seberapa besar kegiatan perkuliahan menyimak yang biasa dilakukan setiap dosen pada mata kuliah menyimak. Karena hal tersebutlah yang biasanya dari dulu yang kebanyakan dosen lakukan dalam setiap perkuliahannya. Hal ini bertujuan untuk melihat seberapa besar kegiatan pengajaran seperti itu masih digunakan di zaman industri 5.0 sekarang ini. Angka tersebut berkategori cukup tinggi penggunaannya walaupun terkesan kuno dan hanya efektif bagi dosen yang terampil dan menarik cara bicaranya dalam menjelaskan materi. Ternyata, keadaan di kelas mengenai pengajaran ini masih cukup berkembang dan masih saja banyak dosen yang menggunakannya. Bukan pengajaran klasikalnya yang keliru tapi intensitas penggunaan pengajaran klasikal ini yang harus kita kurangi. Pengajaran klasikal perlu digunakan hanya saja pada bagian terkecil dalam setiap perkuliahan yang dilakukan agar dosen lebih kreatif dan mahasiswa merasa nyaman dalam kuliah.

Hal ini merupakan perkuliahan menyimak yang biasa-biasa saja tanpa ada kreativitas dosen atau mahasiswa bahkan terkesan monoton dan membosankan. Pembelajaran yang dilakukan seperti menyimak teks yang dibacakan teman atau dosen di depan kelas. Tanpa perlu susah atau rumit menyiapkan media atau bahan cukup baca teks dan suruh mahasiswa mendengarkan dan menyampaikan kembali apa yang ia dapat simak. Terkesan dosen malas dalam menyiapkan pembelajaran menyimak. Pembelajaran tidak dapat dilakukan asal-asalan melainkan harus dilakukan secara terencana dengan baik (Mulyo, Ilyas, dan Ridhani, 2019). 
Perkuliahan tersebut sangat sering terjadi bahkan di zaman sekarang pola belajar seperti disebutkan sebelumnya adalah pembelajaran konvensional bahkan kuno. Mahasiswa membutuhkan bahan simak yang relevan dan menarik dalam pembelajaran tersebut.

\section{b. Banyak Mahasiswa Belum Men- dapatkan Mencapai Kompetensi yang Diharapkan}

Hasil 36\% mahasiswa belum memiliki kompetensi menyimak tersebut. Hal ini tergolong kepada kategori cukup banyak mahasiswa yang belum memiliki kompetensi menyimak tersebut. Sangat disayangkan setelah empat bulan kuliah tentang materi menyimak ia belum mendapatkan kompetensi tersebut. Permasalahan ini harus dilihat dari banyak hal termasuk media yang digunakan selama perkuliahan tatap muka yang pernah dilakukan sebelumnya. Artinya, perkuliahan dengan tatap muka sekali pun hasilnya masih cukup besar mahasiswa yang belum memiliki kompetensi menyimak walaupun sudah mengikuti perkuliahan selama satu semester.

\section{Inovasi yang dibutuhkan}

a. Bahan Simakan melalui Rekaman CD/Audio

Penulis mencari media yang digunakan dosen dalam perkuliahan menyimak ini. Terkhusus pada simakan audio untuk melatih keterampilan menyimak mahasiswa. Seharusnya setiap dosen harus memberikan berupa simakan berupa audio ini karena keterampilan menyimak audio bagian hal dasar dalam perkuliahan menyimak. Menyimak audio, audio-visual bahkan menyimak sebuah visual saja menjadi kebutuhan dasar dalam keterampilan menyimak untuk perguruan tinggi. Audio atau suara merupakan alat untuk menguji daya simak mahasiswa dalam perkuliahan. Hal ini melihat daya tangkap simak, merumuskan di kepala dan menyampaikannya kembali dengan akurat.
Sebenarnya audio memiliki perannya yang baik dalam menguji daya simak mahasiswa. Bagi mahasiswa yang mencapai target dalam menyimak dengan audio sudah dipastikan mahasiswa tersebut memiliki daya simak yang sangat baik. Hanya saja di kelas sebagai pengamatan penulis mahasiswa tidak ingin bahan ajarnya cuma audio saja. Perlu adanya variasi bahan ajar lain sehingga angka yang ditemukan sebagai hasil survei didapatkan tidak sampai setengah dari mahasiswa yang fokus degan bahan audio ini. Berdasarkan temuan tersebut, jelas perlu adanya kreativitas dosen pada perkuliahan menyimak untuk menggunakan audio. Audio tersebut bisa didapatkan dengan mudah dengan mengunduhnya dengan berbagai media yang ada. Dosen pun bisa melakukan rekaman sendiri yang disesuaikan dengan kebutuhan guna memberikan kompetensi menyimak kepada mahasiswa. Mahasiswa pun lebih teruji daya simaknya dengan menggunakan media tersebut. Sehingga kompetensi yang dimaksud dapat dimiliki setiap mahasiswa yang terlibat dalam perkuliahan melalui audio.

\section{b. Bahan Simakan dalam Bentuk Audio-Visual \\ Penulis menambahkan bahan ajar lain} dari pertanyaan survei sebelumnya. Hal tersebut berkaitan dengan penjaringan keinginan dan kebutuhan mahasiswa dalam perkuliahan menyimak. Terbukti bahwa hasilnya 67\% mahasiswa fokus dengan bahan dalam bentuk audio-visual yang diberikan. Kemampuan media ini dianggap lebih baik dan lebih menarik, sebab mengandung kedua unsur jenis media yang pertama dan kedua (Jamilah, Mulawarman, \& Hudiyono, 2020).

Hasil ini jauh lebih besar ketimbang menggunakan audio saja yang hanya bernilai $45 \%$ saja. Bagian ini sudah masuk ranah yang tinggi. Karena dosen lebih kreatif dalam mengajarkan materi menyimak dengan menggunakan media 
audio-visual. Seorang pendidik harus mampu memfasilitasi dan mengarahkan peserta didik sehingga jenis-jenis karakter yang diharapkan dapat meningkat (Sutriyati, Mulawarman, \& Hudiyono, 2019). Media ini sudah tentu biasanya hasil dari pengembangan atau inovasi perkuliahan. Apalagi dilakukan di laboratorium Bahasa. Tentu media tersebut akan memakan biaya yang mahal dalam pengadaannya guna perkuliahan menyimak. Dengan demikian, audio-visual sangan baik dijadikan bahan ajar dalam mendukung penyampaian materi dari perkuliahan menyimak sehingga ini bisa memperkuat fokus dan minat mahasiswa dalam kuliah.

\section{c. Pembelajaran Daring Menggu- nakan Platform Google Classrrom}

Dosen bisa memanfaatkan telepon genggamnya atau bisa dibagikan ke mahasiswa sehingga bisa menyimak masing-masing. Lebih mudah, praktis, dan efisien jika digunakan dalam perkuliahan. Pembelajaran menyimak, khususnya pada masa pandemi, platform pembelajaran daring menjadi alternatif pilihan paling sesuai Hal ini merupakan bagian paling penting dari angket mengenai kebutuhan di masa pandemi. Pendapat ini langsung dari mahasiswa sebagai orang yang terdampak langsung pendidikan dimasa pandemi. Permasalahan ini pun bukan lagi penting atau pun tidak penting tapi mencari solusi alternatif yang bisa menyelamatkan mahasiswa dari virus Covid-19 dengan tetap menjalankan pendidikan. Terbukti hasilnya $62 \%$ berpendapat pembelajaran daring sesuai dengan yang dibutuhkan dalam keadaan seperti ini. Lebih dari setengah dan angka itu pun tergolong sebagai kebutuhan yang tinggi akan pembelajaran daring.

Penulis mencoba mengidentifikasi media yang digunakan, yaitu Google Classroom. Media ini menjadi media yang penulis ukur. Karena media tersebut merupakan media paling dasar yang hampir setiap universitas sudah menggunakannya. Padahal di zaman sekarang hal itu sudah menjadi media sehari-hari yang digunakan dosen dalam membantu perkuliahannya. Apalagi dengan bahan perkuliahan yang banyak dan ribet, seperti buku teks, video, laboratorium virtual, dan lain-lain. Tentunya media ini sangat memudahkan dosen dalam memberikannya kepada mahasiswa. Sudah tidak zamannya lagi memberikannya melalui flashdisk apalagi dalam bentuk CD. Selain itu, kekurangannya ialah tidak terdapat aktivitas dosen dan mahasiswa dalam transfer ilmu dalam rangka perkuliahan. Google Classrrom mampu memenuhi kebutuhan belajar-mengajar di kampus dan terekam dengan baik aktivitas tersebut layaknya perkuliahan di kelas.

Bagian terakhir ini untuk memperjelas media yang digunakan sebagai fasilitas kelas digital yang mumpuni dan terekam dengan baik segala bentuk aktivitas kegiatan belajar-mengajar mata kuliah menyimak. Salah satu yang mumpuni dalam rangking dunia ialah Google Classroom. Google Classroom bisa dikatakan salah satu media pembelajaran yang berbasis metode pembelajaran inkuiri karena Google Classroom dapat melibatkan kemampuan mahasiswa secara maksimal dalam mencari, memahami, menyelidiki, menganalisis dan merumuskan hasil belajar (Gofur, 2018). Ternyata hasilnya sangat tinggi yaitu $78 \%$ mahasiswa membutuhkan media tersebut sebagai kelas digital yang digunakan dimasa pandemi. Lengkap sudah data yang dibutuhkan sebagai pertanyaan terakhir merujuk Google Classroom sebagai kelas digital yang dipilih dalam rangka menghimpun media yang digunakan dalam mata kuliah menyimak dimasa pandemi Covid-19. Apalagi Google Classroom ini gratis, disediakan untuk sekolah, lembaga nonprofit, dan perorangan (Sukmawati, 2020) 
Berdasarkan analisis yang telah dilakukan melalui survei yang telah diterima. Hasil rata-rata semuanya didapatkan hasil 64\% dengan kategori tinggi berdasarkan tabel interpretasi skor (Riduwan, 2013), artinya kebutuhan mahasiswa akan pembelajaran daring pada mata kuliah menyimak dimasa pandemi Covid-19 menggunakan audio dan audiovisual melalui Google Classroom ini tergolong tinggi. Pembelajaran daring di masa pandemi ini jika kita kaji lebih dalam lagi sesungguhnya tidak lagi mengenai mudah atau tidak mudah, efektif atau tidak efektif, melainkan sebagai salah satu solusi pasti yang menyelamatkan mahasiswa dari kehilangan nyawa gara-gara hal tersebut dalam rangka menempuh pendidikan. Hal inilah yang kita butuhkan dalam keadaan sedemikian rupa terlepas dari susahnya jaringan, mahalnya kuota, bertambahnya biaya pendidikan, sulitnya materi masuk, banyak kompetensi atau keterampilan yang kurang bahkan tidak tercapai. Hal tersebut jauh lebih baik dari pada kita ada generasi bangsa terkubur tanah tanpa gelar akademiknya.

Pendidikan kita memang terdampak karena ini tapi jauh lebih baik begini jatuh bangun pendidikan di masa pandemi, tersendat bahkan terlambat, dari pada harus terhenti tanpa ada usaha pendidikan sama sekali. Dosen harus sekreatif mungkin dalam menciptakan pembelajaran daring yang simpel, sederhana, tanpa banyak memakan kuota serta mudah dimengerti mahasiswa. Mahasiswa harus terus berusaha jangan pasrah dengan keadaan. Sinyal susah cari ke tempat yang baik sinyalnya. Biaya kuota yang mahal usahakan cari pekerjaan sampingan untuk memenuhi itu atau bergabung dengan teman yang lain. Pasti ada jalan yang solutif bagi mahasiswa yang bersungguh-sungguh untuk pendidikan yang akan membanggakan orang tua dan sebagai jalan masa depannya. Dengan demikian, pembelajaran daring menyelamatkan mahasiswa dan menyelamatkan pendidikan negara

\section{PENUTUP}

Berdasarkan temuan dan analisis yang telah dilakukan bahwa pembelajaran daring dibutuhkan dalam perkuliahan menyimak. Mahasiswa membutuhkan bahan ajar dalam bentuk audio berupa suara yang bernarasi guna mengasah dan menguji kemampuan menyimak khusus untuk mendengar saja. Kemudian, mahasiswa juga membutuhkan menyimak audio-visual berupa video guna mengasah dan menguji daya simak keseluruhan dari mahasiswa tersebut. Karena dalam masa pandemi Covid-19, keseluruhan hal yang dibutuhkan dalam menyimak tersebut yang sangat diminati mahasiswa ialah dimuat dalam bentuk daring melalui kelas digital dengan platform Google Classroom. Hal itu dibuktikan dengan hasil survei sebesar 64\% mahasiswa membutuhkan pembelajaran daring dengan bahan ajar audio, visual, audio-visual melalui kelas digital Google Classroom. Hasil kebutuhan ini digunakan untuk mengembangkan bahan simakan sebagai bentuk inovasi produk pembelajaran di masa pandemi Covid-19 di kampus. Dengan demikian, dosen diharapkan menyusun dan mengembangkan bahan ajar sekreatif mungkin dengan bentuk yang sederhana, tanpa memakan banyak kuota dan memudahkan dosen mengajar serta memudahkan mahasiswa belajar.

\section{DAFTAR PUSTAKA}

Creswell, J. W. (2014). Research Design Pendekatan Kualitatif, Kuantitatif, dan Mixed. Yogyakarta: Pustaka Pelajar.

Cucinotta, D. \& Vanelli, M. (2020). WHO Declares Covid-19 a Pandemic. Acta Biomed, 91(1), 157-160.

Firman, F. \& Rahayu, S. (2020). Pembelajaran Online di Tengah Pandemi Covid-19. Indonesian Journal of Educational Science (IJES), 2(2), 81-89. 
Gofur, A. (2018). Using Google Classroom on Inquiry Based Learning to Improve Student's Learning Participation. Jurnal Penelitian Pendidikan, 10(2), 15031509. https://doi.org/10.1111/ijcp. 13501

Jamilah, N., Mulawarman, W. G., \& Hudiyono, Y. (2020). Pengembangan Bahan Ajar Interaktif 'POST' dalam Pembelajaran Apresiasi Puisi untuk Siswa Kelas X SMA. Diglosia: Jurnal Kajian Babasa, Sastra, dan Pengajarannya, 3(1), $14-23$. https://doi.org/10.30872/diglosia. v3i1.28

Kuntarto, E. (2017). Keefektifan Model Pembelajaran Daring dalam Perkuliahan Bahasa Indonesia di Perguruan Tinggi. Indonesian Language Education and Literature, 3(1), 99-110.

Milman, N. B. (2015). Distance Education. In International Encyclopedia of the Social \& Behavioral Sciences (pp. 567-570). Elsevier. https://doi.org/10.1016/B978-008-097086-8.92001-4

Mulyo, S., Ilyas, M., \& Ridhani, A. (2019). Pembelajaran

Keterampilan
Berbicara dengan Metode Field Trip pada Peserta Didik Kelas IX SMP Samarinda. Diglosia: Jurnal Kajian Bahasa, Sastra, dan Pengajarannya, 2(2), 115-126.

Riduwan. (2013). Skala Pengukuran Vaiabel-Variabel Penelitian. Bandung: Alfabeta.

Stein, R. A. (2020). COVID-19 and rationally layered social distancing. International Journal of Clinical Practice, 74(7). https://doi.org/10.1111/ijcp.1350 1

Sukmawati. (2020). Implementasi Pemanfaatan Google Classroom dalam Proses Pembelajaran Online di Era Industri 4.0. Jurnal Kreatif Online, $8(1), 39-46$.

Sutriyati, Mulawarman, W. G., \& Hudiyono, Y. (2019). Pengembangan Bahan Ajar Menulis Esai Dengan Memanfaatkan Kearifan Lokal Melalui Pembelajaran Berbasis Proyek (PBP) Siswa SMA. Diglosia: Jumal Kajian Babasa, Sastra, Dan Pengajarannya, 2(1), 39-46. https://doi.org/10.30872/diglosia. v2i1.16 